\title{
Research on the Reform of Pronunciation Teaching in Business English Major
}

\begin{abstract}
SONG Zong-wei
Binzhou University, Binzhou, China

Traditionally, English pronunciation teaching in universities in China is always focused on the theoretical teaching in classroom, which cannot meet the requirements of society. At the same time, the new national standard of business English major puts forward higher demands of the educational objectives of the course. In order to adapt to the reform of business English major, university teachers of English pronunciation course should be active in promoting the curriculum reform. This paper proposes to make suggestions to change the traditional theory teaching of classroom and to improve the students' practical skills by training.
\end{abstract}

Keywords: practice teaching, English pronunciation, business English major

\section{Introduction}

Recent years, business English major in China has developed greatly. Up to 2015, about 250 colleges and universities nationwide have opened the business English major. At the same time, the business English major is undergoing reform. According to the new national standard of business English major, great changes have taken place in the curriculum provision. In the curriculum provision, the new requirements only reserve English pronunciation and grammar, which can be seen as a major reform of the business English major (LIU, 2015, p. 82). According to WANG (2015, p. 297), practice teaching should be valued to achieve the goal of cultivating the applied talents to meet the demands of the business English reform. The rapid development of China increases higher demands not only for business English majors but also for English pronunciation.

As a very important part of business English major in universities, the reform of English pronunciation teaching is related to the success of the reform of business English major in China. At the same time, it also plays a vital important role in achieving the desired objectives of business English major. English pronunciation teaching in China is always overlooked in most of universities in China. To meet the demands of the reform and opening up, only graduates of business English major have fluent oral English can they finish their daily work. The new situation of the economy and the development of the "Belt and Road" require that the teaching of English pronunciation should be changed.

\section{Literature Review}

Along with the deepening of the reform and opening-up of China, the foreign business activities are getting

SONG Zong-wei, assistant, M.A., Foreign Language Department, Binzhou University, Binzhou, China. 
more and more, which makes for business English teaching higher requirements. Many employers put forward higher request to the English professional talents. So, to cultivate "applied talents" becomes one of the training objectives in most universities.

The reform of practice teaching of the English pronunciation in higher vocational colleges is focused on the "theory teaching and practice teaching design research", such as the whole class design, combining with students' learning and teachers' teaching; the teaching research, combining with the in-class and after-class teaching; and the study of the second and third class. Studies of English pronunciation teaching in local undergraduate universities mainly focus on the theoretical research, such as the study of English pronunciation teaching and research, the study of teaching English pronunciation and dialect, the study of the assessment mechanism, and the study of training modes of business English major. The new version of the The National Standard for the Quality of business English major in Universities further highlights the characteristics of international-orientation, compound talents, and applied talents (WANG, 2015, p. 297). Under the background of the new national standard, the reform of the theory and practice teaching is the internal requirement of business English major.

To sum up, in view of the training objective of cultivating applied talents, local colleges and universities should build theory and practice teaching system. Through the business English training room, teachers will further improve the communication ability and familiarize students with the complex foreign business English activities.

\section{Expected Goals}

(1) To establish the modular contents of the "theory and training" teaching.

The intonation, rhythm, and the flow of the language are always neglected in traditional teaching method, which only values the drill of pronunciation. Based on the characteristics of business English major, its teaching content should be modular.

Theory teaching module should be focused on the core concept of modular. Phonetic sounds, pronunciation variations, tone, and rhythm should be integrated into the English pronunciation teaching. The module of the theory teaching can be divided into four parts, syllables and phoneme, sentence rhythm, pronunciation variations, and intonation

Practice teaching is a necessary complement to classroom theory teaching. Training room of Business English makes it possible for the practice teaching. The practice teaching should be modular, which can be divided into six modules, sounds listening and correcting, sentences pronunciation training, Business English spoken language training, famous movie appreciation, classic dialogue, the original speech paragraph appreciation and social communication practice.

(2) To establish the teaching objectives of "theory and training" teaching.

The teaching objectives of "theory + practice" teaching can be divided into ability objective, knowledge ability, and quality ability. It is committed to making qualified talents of business English major.

(3) To establish the teaching plans of "theory and training" teaching.

There are three stages to carry out the "theory and training " teaching. The first is the explanation of basic knowledge of pronunciation. The second is the training under real language materials and contexts. The third is the use of English pronunciation in the foreign business activities 


\section{Problems in Pronunciation Teaching and Improvement Proposals}

\section{Problems}

English pronunciation is regarded as a basic and compulsory course for English majors in China. And usually, it is opened when students in the fresh year. For example, in Binzhou University, English majors, including business English majors, should learn this course before the end of the first term of their college life. However, most students cannot utilize the theory learned from the classroom. What is more, they cannot speak English fluently and even make different kinds of mistakes in pronunciation. The main reasons can be attributed to the following aspects.

(1) Overall speaking, it is quite common that the freshmen have a weak foundation in English. The English teaching in senior high school in China is focused much attention on English grammar. Influenced by the examination-oriented education pattern, grammar and vocabulary teaching is the most important part in junior and senior high school (XU \& LI, 2011, p. 167). Influenced by local dialects, some students cannot pronounce English correctly; some students speak English with heavy local accent. Many students do not have language awareness and are poor in verbal communication.

(2) The single teaching method is another problem in the English pronunciation teaching. In class, the traditional method is that teacher explains how to pronounce and then students read after teacher. And most teachers still adopt the traditional teaching method in China now. They use the blackboard to explain the pronunciation theory and pay more attention to teaching basic knowledge systematically. This method has both advantages and disadvantages. On the one hand, it is truly useful for students to master the basic knowledge, such as syllable, accent, intonation patterns, etc. However, there still exits some problems. The traditional method is teacher-oriented. As a result, students feel bored and they lack the opportunity to practice English sounds. Even most students can only accept the teaching content passively. The students' subjective ability of learning is restricted and they are not interested in learning and practicing English sounds.

(3) The evaluation method of English pronunciation is single. Generally speaking, there are two ways to evaluate students performance of learning the course. One is to finish a test paper when students finish the course. The other is oral English test.

\section{Improvement Proposals}

In order to satisfy the increasingly urgent need of the Chinese economy, English pronunciation for business English major should have some changes.

(1) The teaching methods should be diversified, interesting, and students-oriented.

The teacher should use the Internet and multimedia technology to take place the traditional teacher's explanation. English pronunciation should be taught in language lab and the teacher can use the Internet to enrich the teaching content. Relatively, the traditional method of explanation and demonstration is monotonous and students cannot keep their focus on what the teacher says in class. By using of the mufti-media, the teacher can make the pronunciation teaching vivid. For example, using the animation and video, in stead of traditional explanation, to show students how every international phonetic symbol is pronounced; The pronunciation of the animation and video can be a good substitute for the teacher's pronunciation demonstration (XU \& LI, 2011, p. 168). By using the Internet and choosing some classical movies and speech, the teacher can encourage students to 
imitate the pronunciation of the native speaks. Also, the use of the Internet and multimedia can provide students more materials, including recordings and TV programs. The use of multimedia helps students to solve the problems met in the process of learning pronunciation and is useful for students to imitate spoken English in the real context.

Another very useful way to encourage students to participate English pronunciation learning is to make full use of the on-line autonomous learning, which is a good way to check the learning efficiency of English pronunciation. At present, online autonomous learning English in colleges and universities has already become an important objective of the reform of college English teaching. Take Binzhou university as an example, all the students should finish the task of English by learning from the Internet and the learning outcomes will be a very important part of the grade evaluation. By on-line autonomous learning, students can broaden their horizons and become more interested in pronunciation learning. In addition, students can be accessible to high-qualify digital learning resources, such as national high-quality English course (XU, 2012, p. 212). The on-line autonomous learning not only makes students more interested in learning pronunciation but also cultivates their ability to study independently.

(2) The second classroom and the third classroom activities should be used.

The second classroom complements the class teaching. After many years development, it has many forms in college and university English learning. As for the pronunciation learning and teaching, there are several kinds of second classroom activities that can be chosen. The English club and English corner activities are the most common forms of second class in English learning, which have been launched in most of the universities in China (BAI, 2011, p. 153). For example, in Binzhou university, there is an English corner that foreign English teachers, Chinese professional English teachers and English majors, and business English majors join together on weekends. Every time they have some discussions for a specific topic. Students are encouraged to express their personal opinions about the topic. They can share their opinions with teachers and classmates. At the end of the activity, there is always a comment made by foreign teachers. Foreign teachers correct some sounds and help students to strengthen their pronunciation. Chinese teachers also help students drill the rhythm and intonation. By participating the English corner, students have the opportunity to speak English and train their English pronunciation. Some other second classroom activities, such as English Speaking Contest, English Dubbing Contest, English Song Contest can also be good ways for students' English pronunciation training.

In a broaden sense, the third classroom in universities refers to different social activities. Business English majors should take part in social activities to improve their communication ability. For instance, China Import and Export Fair, also known as the Canton Fair, is a very good third classroom stage. Business English majors should be encouraged to become volunteers. Taking part in activities like this can give students a good opportunity to communicate with foreigners and improve their pronunciation. Local colleges and universities should also encourage students to participate different kinds of activities and meetings. For example, the 2nd China National Conference on historic villages was held in Binzhou in 2016. Forty-seven guest speakers, more than 1,100 people from China, Germany, Italy, south Korea, Japan, Spain, Russia, and Canada attended the conference. More than 100 business English majors in Binzhou University helped to receive the guests. Attending the conference not only gives students a great opportunity to practice English pronunciation but also improves their communication ability. 
(3) The assessment method of the pronunciation should be diversified.

It is necessary to establish the assessment methods of the English pronunciation for business English major. The assessment requires specific inspection standard, reasonable distribution of the assessment content and grades. The proportion of procedural examination should be strengthened and the proportion of the final exam should be reduced.

\section{Conclusion}

English pronunciation is the foundation to accomplish kinds of foreign business affairs for business English majors. In order to achieve the training goals of business English, teachers should adopt new teaching methods. In addition, teachers should make full use of the modern technology to provide students with different kinds of training materials. Students should be encouraged to practice their pronunciation. Theory and training teaching provides a new approach of pronunciation teaching for business English major.

\section{References}

BAI, Y. M. (2011). A study on the status of extracurricular college English activities and the counter measures. Journal of Xichang College: Social Science Edition, 23(1), 154-155.

LIU, Y. H. (2015). Interpretation of essentials of national standards for teaching quality of business English major. Journal of Language and Literature Studies, 9, 82-83.

WANG, L. F. (2015). Interpretation of essentials of national standards for teaching quality of business English major. Foreign Language Teaching and Research (bimonthly), 47(2), 297-298.

XU, L., \& LI, H. (2011). Exploration of business English pronunciation teaching design. Journal of Changchun University of Science and Technology, 6(9), 167-168.

XU, Y. (2012). Research on the teaching reform of English pronunciation training of business English specialty of higher vocational education. Journal of Jiamusi Education Institute, 5, 212. 